\title{
TELL SABI ABYAD, SYRIA: RADIOCARBON CHRONOLOGY, CULTURAL CHANGE, AND THE 8.2 KA EVENT
}

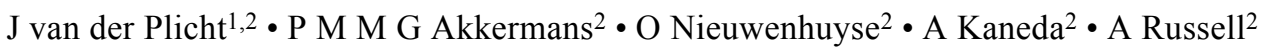 \\ ABSTRACT. At Tell Sabi Abyad, Syria, we obtained a robust chronology for the 7th to early 6th millennium BC, the Late \\ Neolithic. The chronology was obtained using a large set of radiocarbon dates, analyzed by Bayesian statistics. Cultural \\ changes observed at $\sim 6200 \mathrm{BC}$ are coeval with the $8.2 \mathrm{ka}$ climate event. The inhabitation remained continuous.
}

\section{INTRODUCTION}

Climatic variations are observed in various proxy records during the Early Holocene, the most pronounced one the so-called " 8.2 ka event," 8200 yr ago (Alley et al. 1997). This abrupt climate change event, caused by drainage of a huge glacial meltwater lake in North America, was first (and still is) most notably observed in the Greenland ice, and is characterized by a $\sim 160$-yr-long cooling period of $\sim 3{ }^{\circ} \mathrm{C}$ (Kobashi et al. 2007). This event has been observed in marine, lacustrine, and terrestrial records, mainly on the Northern Hemisphere (Rohling and Pälike 2005; Wiersma 2008).

Both climatologists and policy makers today have come to appreciate that archaeological insights in human responses to climate change in the past are highly relevant for our own modern society facing future climate change. The $8.2 \mathrm{ka}$ event has been used as an example in popular blockbuster movies (in particular, The Day After Tomorrow) and in a recent White House policy report (Schwartz and Randall 2003). In spite of this emphasis, however, we remain virtually in the dark with regard to understanding how prehistoric communities coped with this event. Archaeologists have recently suggested dramatic socioeconomic downfalls, massive population migrations, increases in violence and warfare, and general mayhem in Europe and the Near East as a result of the event (Weiss and Bradley 2001; Weiss 2003; Weninger et al. 2006), but sound data for confirming such dramatic scenarios are mostly absent. The full understanding of the $8.2 \mathrm{ka}$ event, including its temporal aspects, needs to be improved (Morrill and Jacobsen 2005; Jansen et al. 2007).

Evidently, apart from the human response, it is crucial to ascertain firm chronologies. At a recent workshop dedicated to the $8.2 \mathrm{ka}$ event, one of the main conclusions was that “.... significant problems remain. The most important and one that was repeatedly raised was that of chronology. The offset (around 200 years) in the terrestrial dates for the drainage and the ice core chronologies, while within error bars, is still quite significant" (Schmitt and Jansen 2006).

Chronologies are an essential first step for synchronizing climate and culture change. Of course, while fully recognizing that synchronicity does not by itself imply causality, it is also clear that discussions of human responses to past climate change are often hampered by poor chronological control. With insufficient control over archaeological sequences, it becomes dangerously easy to "match" cultural sequences to make them fit reconstructed patterns of climate change. Both socalled climate determinists and cultural determinists must be able to rely on sound chronological frameworks, both for climate and for cultural change.

Here, we present a significant contribution to both the chronology of the climate event as well as to its human response, obtained from what is possibly the best data set for investigating the repercussions of the 8.2 ka event in the Near East: the Late Neolithic site Tell Sabi Abyad in northern Syria.

\footnotetext{
${ }^{1}$ Center for Isotope Research, Groningen University, Groningen, the Netherlands. Corresponding author. Email: j.van.der.plicht@rug.nl.

${ }^{2}$ Faculty of Archaeology, Leiden University, Leiden, the Netherlands.
} 
Extensive excavations during the past 25 yr revealed a unique, continuous sequence of 7 th and early 6th millennium occupation layers, unparalleled at any other site in the Near East so far (Akkermans and Schwartz 2003). The layers of settlement have been extensively dated by radiocarbon, which showed that habitation at the site encompassed the $8.2 \mathrm{ka}$ event. Altogether, $145{ }^{14} \mathrm{C}$ dates were analyzed by Bayesian statistics, establishing the best-dated chronology for a Late Neolithic site in the Near East thus far. Here, we present the dates and their analysis, and discuss the consequences of our research in terms of the 8.2 ka event.

\section{THE EXCAVATIONS AT TELL SABI ABYAD}

Tell Sabi Abyad is a Neolithic archaeological site in northern Syria (see Figure 1). It is located in the Balikh Valley, about $30 \mathrm{~km}$ from the Syro-Turkish border. The region is rather marginal for dry farming (200-300 mm annual precipitation). Even small changes in the amount of precipitation in this region can have drastic results, in the past as well as today - as seen in the present-day drought period that has hit Syria (Akkad 2009). Indeed, climate models predict for the region considered here a shift to drier and colder conditions during the $8.2 \mathrm{ka}$ event (Wiersma and Renssen 2006). This makes the site a prime test case for investigating the human response.

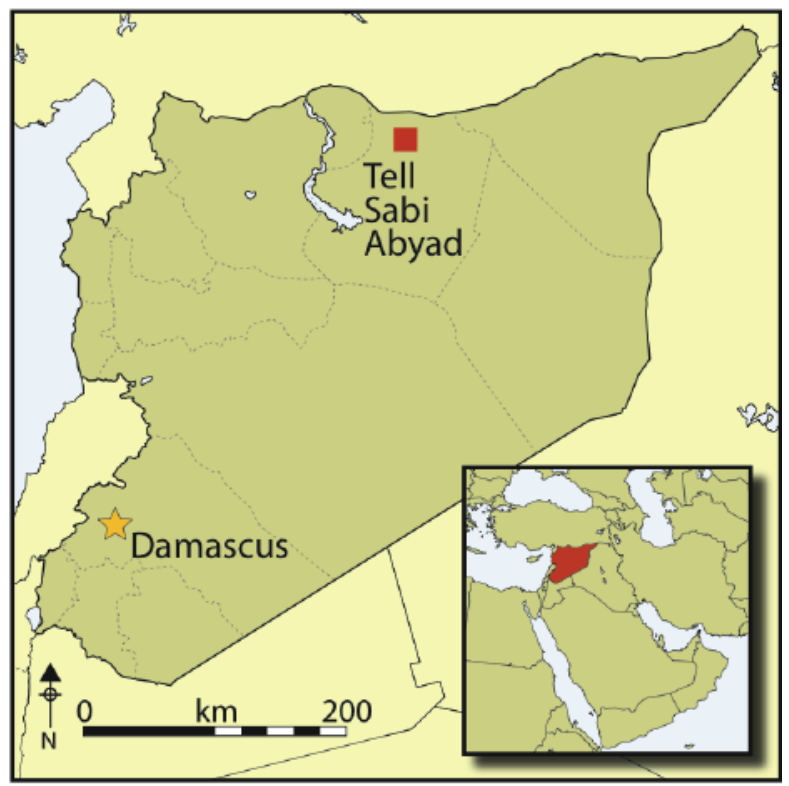

Figure 1 The location of Tell Sabi Abyad in northern Syria

The mound of Tell Sabi Abyad has been shown to have a highly complex history of settlement. This article is primarily concerned with the extensive excavations in the northwestern area of the site, termed Operation III. The work in Operation III revealed 4 successive phases of deposition, which we have named Sequence A ( 7100-6200 BC), Sequence B ( 6200-5900 BC), Sequence C ( $\sim 5900-5800 \mathrm{BC})$, and Sequence D ( 5700-5500 BC). A schematical drawing of the site indicating the various stratigraphic phases is shown in Figure 2.

The excavations in Operation III show that the earliest stratigraphic phase (sequence A) is comprised of at least 12 distinct levels starting during the Initial Pottery Neolithic (7000-6700 BC) and continuing through the Early Pottery Neolithic into the early stages of the Pre-Halaf Pottery stage 


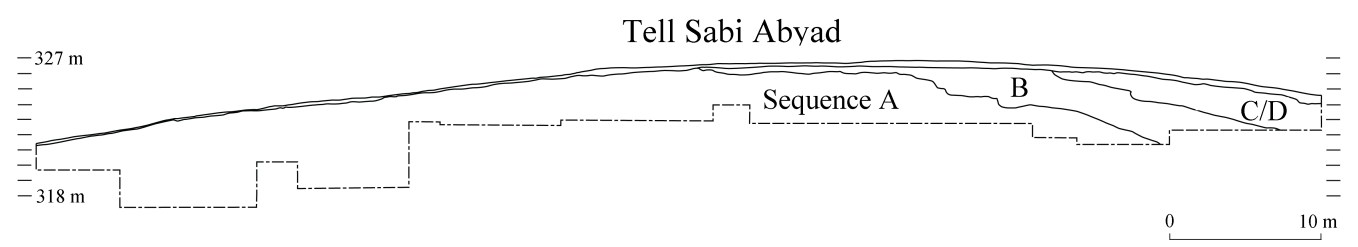

Figure 2 Schematic illustration of the so-called Operation III excavations at Tell Sabi Abyad. Sequences A and B are discussed in this paper; sequences $\mathrm{C} / \mathrm{D}$ are not.

(until $6200 \mathrm{BC}$; see Nieuwenhuyse et al. 2010 for the terminology). Sequence B continues with a sequence of at least 8 levels after $\sim 6200 \mathrm{BC}$ (Pre-Halaf and Transitional periods). This is followed by deposits dated to the Early Halaf (Sequence C) and the Middle Halaf (Sequence D) periods.

For the present paper, only sequences $\mathrm{A}$ and $\mathrm{B}$ are relevant. There are noticeable differences between sequences $\mathrm{A}$ and $\mathrm{B}$, suggesting that the transition between these 2 periods was realized within a short timespan around 6200 BC (Akkermans et al. 2006).

\section{ABRUPT CULTURAL CHANGE IN THE LATE NEOLITHIC ABOUT 6200 BC}

Around $6200 \mathrm{BC}$, the inhabitants shifted the location of their village from the high western part of Tell Sabi Abyad, where continuous occupation over almost a millennium had accumulated a steep tell, towards the eastern slopes of this ancient mound. That is, the village moved from west (Sequence A) to east (Sequence B). This was not a very drastic move, as the site as a whole was never deserted, but the shift was associated with the spread of new architectural forms. Large storage buildings consisting of many tiny cubicles made their appearance. Circular buildings (tholoi), which were found incidentally in the earlier 7th millennium, now suddenly occurred in large numbers. The community transformed from autonomous households with a subsistence based on agriculture and domesticated ovicaprids and pig, towards a much more diversified population that included both mobile pasturalists and sedentary agriculturalists.

Zoological studies and residue analyses point to key changes in animal husbandry, notably the use of sheep and goats for milk and fiber production (Evershed et al. 2008; Russell 2010). A "fiber revolution" is suggested by a substantial increase in the number of spindle whorls after $6200 \mathrm{BC}$; their size and weight suggest they were used for wool production. Finally, animal exploitation patterns show a substantial (albeit temporary) reduction of pig husbandry in favor of cattle. This change can possibly be linked to an aridification of the environment caused by the $8.2 \mathrm{ka}$ event, as pigs are particularly maladapted to arid conditions (Balter 2010; Russell 2010).

Accompanying changes include the introduction of stamp seals and abstract tokens to control access to goods or services, pointing to changing concepts of personal property. The material culture furthermore shows the development of advanced ceramic storage containers and the introduction of new types of cooking ware. There were significant changes in the social-symbolic roles of ceramics as well, as indicated by the sudden introduction and subsequent rapid increase of ceramics decorated with abstract, geometric motifs. Decorated pottery styles were becoming similar over vast geographic distances, pointing to significantly increased social networking. The lithic industry saw a technical disinvestment in stone tool manufacture; the consumption of stone axes and of stone vessels was reduced significantly (Akkermans et al. 2006, 2009, 2010; Nieuwenhuyse et al. 2010).

All these cultural changes took place or began to manifest themselves around $6200 \mathrm{BC}$; they started during level A1 and were mostly fully implemented during level B8, i.e. within a short timeframe. 
It is striking that these cultural changes all took place around the time of the $8.2 \mathrm{ka}$ climate event. To investigate the possible contemporaneity of the "cultural event" with the "climate event," a good chronology for the occupation sequences at Tell Sabi Abyad is necessary. This was established by an extensive ${ }^{14} \mathrm{C}$ dating program.

\section{DATING THE LATE NEOLITHIC SEQUENCE AT TELL SABI ABYAD}

For the 7th to early 6th millennium BC layers of Tell Sabi Abyad, more than $300{ }^{14} \mathrm{C}$ dates have been obtained thus far. All ${ }^{14} \mathrm{C}$ dates were measured at the Groningen radiocarbon facility. For the socalled Operation III series of excavations, the many building levels corresponding to sequences A and B (see Figure 2) were sampled for ${ }^{14} \mathrm{C}$ dating. Most samples discussed here were obtained during 2005-2009. From our extensive set of dated samples, 246 were selected as our "first choice" data set. Of these, 239 are accelerator mass spectrometry (AMS) dates (laboratory code GrA); 7 were conventional (laboratory code GrN). The routing through the AMS or conventional laboratory was determined by sample size only. There are 83 dates for fossil bones (both human and faunal), and 163 dates for charcoal, (charred) seeds/grains, and a single small sample of wood.

In this paper, we do not discuss the bone dates; we only use the dates provided by the charred botanical samples. The extensive sample of charcoal/seed dates is preferred because they provide more certainty for stratigraphic (Bayesian) analysis. Practically all samples designated as charcoal in the date list represent in fact unidentified seeds/grains, shrubs, and twigs, i.e. short-lived sample material. Possible "old wood effects" are not an issue here (see also Bruins et al. 2011). The samples come from a closed context: collected from bin fills, ovens, hearths, and rooms. Thus, they represent primary fills: the contents of the fireplace, perfectly dating the last usage of the fireplace and its association. The samples therefore fulfill the stringent requirements for Bayesian analysis (e.g. Bayliss 2009). Samples taken from pits and open areas are less reliable and therefore not used, since they may date to different periods.

The analysis of the bone samples is more problematic, which is the reason they are not (yet) used for the Bayesian analysis, which requires prime quality sample material (Bayliss 2009; Bronk Ramsey 2009). A large sample of faunal bones has been analyzed for the stable isotopes ${ }^{13} \mathrm{C}$ and ${ }^{15} \mathrm{~N}$ (Russell 2010). In terms of standard ${ }^{14} \mathrm{C}$ sample quality parameters like collagen content, $\mathrm{C} \%, \mathrm{~N} \%$, and $\mathrm{C} / \mathrm{N}$ ratios (e.g. van Strydonck et al. 1999), the success rate was only around 30\%. The success rate for the bones from the human burials that were dated by ${ }^{14} \mathrm{C}$ is comparable. A large (>100 bones) sample of burials is still waiting processing in Groningen. When these are analyzed, we will have a better understanding of the quality and degradation process, enabling us to select bone dates possibly acceptable to be included in the Bayesian analysis.

The list of 163 dates with their context is given in the Appendix. The dates are reported in BP, and the calibrated date ranges in BC (1- $\sigma$ confidence level). All numbers are rounded to the nearest 5 . Of these dates, 18 were identified as outliers, leaving 145 samples for the ultimate Bayesian analysis: 109 for sequence $\mathrm{A}$ and 36 for sequence $\mathrm{B}$.

With only very few exceptions, all samples underwent the standard AAA pretreatment. All accepted dates satisfy the usual sample quality criteria: the carbon content of charcoal should be $68 \pm 5 \%$, and the $\delta^{13} \mathrm{C}$ value should be around $-22 \%$ (Mook and Streurman 1983; van Strydonck et al. 1999). There is one $\delta^{13} \mathrm{C}$ value that shows $\mathrm{C}_{4}$ plant material $\left(\delta^{13} \mathrm{C}=-14.69 \%\right)$; interestingly, this sample had to be rejected because it is a large outlier in age. 
In the timeframe of interest here, calibration of individual ${ }^{14} \mathrm{C}$ dates yield complex and broad probability distributions. The temporal resolution on the calendar timescale is then not good enough to derive precise chronological inference. The temporal resolution can significantly be improved by additional information to the ${ }^{14} \mathrm{C}$ dates, by applying Bayesian statistics. This enables calibrated ${ }^{14} \mathrm{C}$ ages to be included along with their relative archaeological stratigraphy (Bronk Ramsey 2001, 2009; Bayliss 2009). Only selected dates with good quality can be used, from both the ${ }^{14} \mathrm{C}$ laboratory point of view, as well as archaeology: most importantly, a clear context (e.g. van der Plicht et al. 2009). In the case of Tell Sabi Abyad, this is the selection of 145 samples mentioned above.

The Bayesian analysis of both sequences (A and B) was performed using the OxCal v 4.1 program (Bronk Ramsey 2009) and the IntCal09 calibration curve data (Reimer et al. 2009). The dates were grouped per level separated by boundaries. The numbers are summarized in Table 1 (Sequence A) and Table 2 (Sequence B). The tables show the levels, the number of ${ }^{14} \mathrm{C}$ dates per level, and the calibrated date ranges (1- $\sigma$ level) in $\mathrm{BC}$ calculated by OxCal.

Table 1 Results of Bayesian analysis: date ranges for sequence A.

\begin{tabular}{lcl}
\hline Level & nr of ${ }^{14} \mathrm{C}$ dates & Date range $(\mathrm{BC})$ \\
\hline $\mathrm{A} 1$ & 23 & $6330-6225$ \\
$\mathrm{~A} 2$ & 16 & $6385-6325$ \\
$\mathrm{~A} 3$ & 6 & $6395-6375$ \\
$\mathrm{~A} 4$ & 15 & $6455-6385$ \\
$\mathrm{~A} 5$ & 8 & $6485-6450$ \\
$\mathrm{~A} 6$ & 2 & $6505-6480$ \\
$\mathrm{~A} 7$ & 14 & $6570-6490$ \\
A8 & 7 & $6625-6575$ \\
A9 & 4 & $6675-6620$ \\
A10 & 6 & $6760-6680$ \\
A11 & 4 & $6825-6760$ \\
A12 & 4 & $6865-6775$ \\
\hline
\end{tabular}

Table 2 Results of Bayesian analysis: date ranges for sequence B.

\begin{tabular}{lcl}
\hline Level & $\mathrm{nr}$ of ${ }^{14} \mathrm{C}$ dates & Date range $(\mathrm{BC})$ \\
\hline B3 & 2 & $6040-5995$ \\
B4 & 4 & $6050-6015$ \\
B5 & 6 & $6075-6040$ \\
B6 & 5 & $6095-6065$ \\
B7 & 6 & $6125-6080$ \\
B8 & 13 & $6180-6105$ \\
\hline
\end{tabular}

The results show a consistent and continuous chronology of the Late Neolithic levels. In 2 cases (levels A1 and B8), a subdivision of 4 and 3 levels, respectively, can be made, based on the sequence of ovens and hearths. This is not further discussed here.

The calculated age ranges (Tables 1,2) are shown graphically in Figure 3. The figure shows the complete chronology of the Late Neolithic sequence in Operation III during the 7th and early 6th millennia. The inhabitation is continuous; the chronology of sequence $\mathrm{A}$ is followed by sequence $\mathrm{B}$. At first sight, Figure 3 seems to indicate a short break between occupation levels A1 and B8. However, the hiatus does not exist in reality, as there is a level B9-albeit without ${ }^{14} \mathrm{C}$ dates so far. Stratigraphically, this level B9 bridges the gap between the levels A1 and B8. 


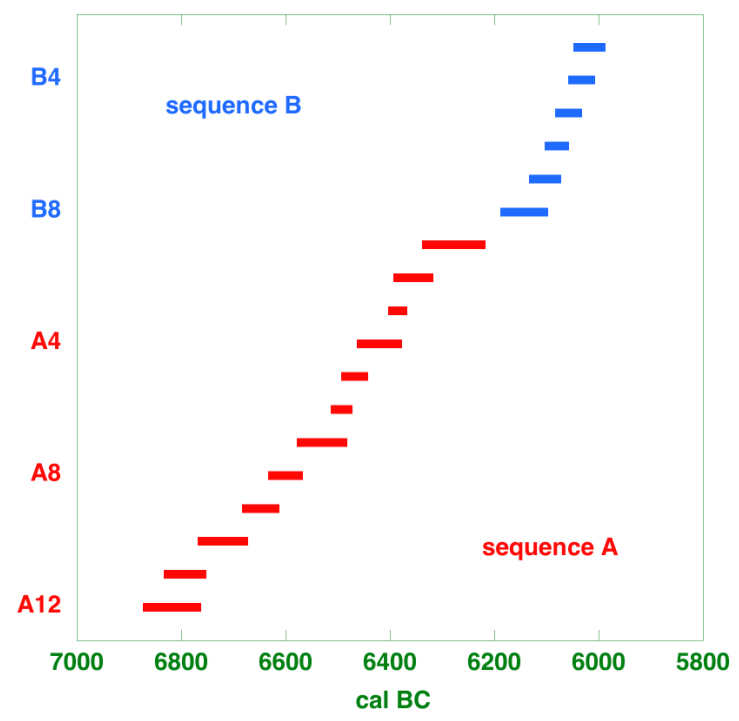

Figure 3 High temporal resolution ${ }^{14} \mathrm{C}$ chronology of the archaeological levels of Tell Sabi Abyad.

The OxCal program calculates the boundaries "end sequence A" and "beginning sequence B" as well. Statistically, these boundaries overlap at the $1-\sigma$ confidence level.

\section{THE CHRONOLOGY OF THE 8.2 KA EVENT AS DERIVED FROM CLIMATE PROXIES}

Unfortunately, no pollen records or other such direct climate proxies are available at Tell Sabi Abyad. However, the $8.2 \mathrm{ka}$ climate event has been observed in many records elsewhere during the last decade (for a recent review, see Wiersma 2008 and references therein). Here, we discuss only those records most relevant for the chronological aspects of the $8.2 \mathrm{ka}$ event. We concentrate on those proxies that are dated directly, by dendrochronology, ice counting, and, in particular, by ${ }^{14} \mathrm{C}$. They are summarized in Figure 4, plotted for the time range 8800-7800 cal BP. The event started with the drainage of Lake Agassiz. This was a "superlake" on the North American continent, caused by melting of the retreating Laurentide Ice Sheet (Clarke et al. 2003).

In marine records, the $8.2 \mathrm{ka}$ climate event is ${ }^{14} \mathrm{C}$ dated with relative large uncertainty to $8160-8740$ cal BP (Barber et al. 1999). The event is coeval (8380-8290 cal BP) with a significant reduction of the North Atlantic Deep Water (NADW) formation, as observed in the Labrador Sea (Kleiven et al. 2008). Also, the cold meltwater appeared to come in 2 pulses, the first $\sim 8500 \mathrm{yr}$ ago, the second 200 yr later: $8280-8380$ and $8470-8580$ cal BP, respectively. This was inferred from reading the history of both surface and bottom waters in a single marine core (Ellison et al. 2006). We note that (for the ${ }^{14} \mathrm{C}$ aspects) these marine records suffer from uncertainties in reservoir corrections (in particular during times of climatic upheavals).

The event is (given the published chronologies) followed by a sharp cooling event on Greenland, as observed in ice cores (Kobashi et al. 2007; Thomas et al. 2007 and references). Taken together, the time range for the event (analyzed for a composite of ice-core records Dye3/GRIP/GISP2 and NGRIP) is $8247-8025$ cal BP. The ice-core records represent a high temporal resolution; the counting error (absolute timescale error) of the ice layers is stated as $\sim 50 \mathrm{yr}$. 


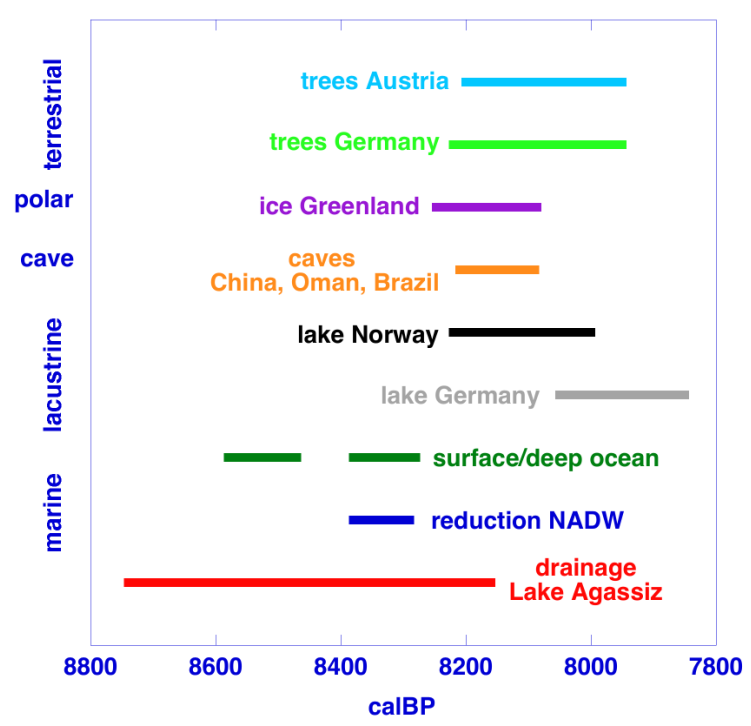

Figure 4 Chronological comparison of the $8.2 \mathrm{ka}$ event as observed in selected proxy records from marine, lacustrine, polar, and terrestrial environments. For references, see the text.

Lacustrine climate proxy records were the first terrestrial records yielding chronological information for the $8.2 \mathrm{ka}$ event. Variations in stable oxygen isotope ratios of ostracod valves from Lake Ammersee (southern Germany) for the first time confirmed the 8.2 ka climate event in Europe (von Grafenstein et al. 1998). The core is ${ }^{14} \mathrm{C}$ dated but the absolute age model is not robust. From this article, we infer a time range of 8050-7850 cal BP for the event. More recently, the $8.2 \mathrm{ka}$ event is well dated in a lake from Norway, by applying ${ }^{14} \mathrm{C}$ wiggle-matching of terrestrial macrofossils (Hormes et al. 2009). The resulting age range for the $8.2 \mathrm{ka}$ event is $8000-8220 \mathrm{cal} \mathrm{BP}$.

A combination of speleothem records from Brazil, China, and Oman clearly show the 8.2 ka event. The chronology is obtained from U-series-dated ${ }^{18} \mathrm{O}$ paleoclimate records. The $8.2 \mathrm{ka}$ event is dated to $8090-8210$ cal BP (Chen et al. 2009).

In pure terrestrial records, the $8.2 \mathrm{ka}$ climate deterioration is observed in tree-ring replication records in central Europe. In terms of chronologies, these can be considered the best proxies, because dendrochronology provides an absolute timescale. In German tree rings (subfossil oaks from the Main River), the $8.2 \mathrm{ka}$ event is observed at 8220-7950 cal BP (Spurk et al. 2002). In trees from the Austrian Alps, the event is observed at 8200-7950 cal BP (Nicolussi et al. 2009). Both central European tree-ring chronologies for the $8.2 \mathrm{ka}$ event are consistent with each other, as well as with the Greenland ice cores.

The age ranges for the $8.2 \mathrm{ka}$ event mentioned above are shown in Figure 4. The data, selected from the literature, are representative for dating the $8.2 \mathrm{ka}$ event in marine, lacustrine, polar, and terrestrial records.

\section{DISCUSSION: SYNCHRONIZING CLIMATIC AND CULTURAL EVENTS}

The chronology for Tell Sabi Abyad, as obtained from the ${ }^{14} \mathrm{C}$ analysis, is shown in Figure 5, which is essentially the same as Figure 3, but now includes a comparison with the chronology obtained for the $8.2 \mathrm{ka}$ event. For the latter, we show only the $8.2 \mathrm{ka}$ event as observed in ice cores, using the 
chronology of Thomas et al. (2007) for the combined Greenland ice cores, which is also consistent with the tree rings.

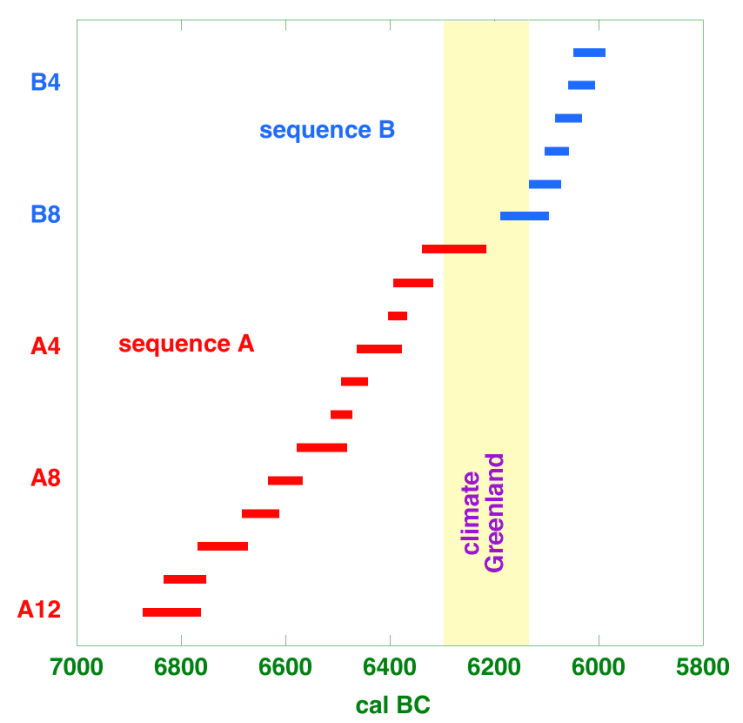

Figure 5 High temporal resolution ${ }^{14} \mathrm{C}$ chronology of the archaeological levels of Tell Sabi Abyad (same as in Figure 3), compared with the duration of the 8.2 ka climate event as observed in Greenland ice cores.

This comparison shows that the stratigraphic transition from Sequence A to B, which represents the onset of large-scale societal change during the otherwise continuous inhabitation at Tell Sabi Abyad, is clearly contemporaneous with the 8.2 ka climate event. The societal changes at Tell Sabi Abyad started at the timeframe corresponding to level A1, and are fully implemented at level B8. The data can be interpreted as a long-lasting period of gradual change, accelerated during the transition from Sequence A to B.

It is striking that a similar observation is made by Rohling and Pälike (2005) in their review article on the $8.2 \mathrm{ka}$ event. They note that the climate anomalies span $400-600 \mathrm{yr}$, starting $\sim 8600 \mathrm{yr}$ ago, and that more sudden climate changes $\sim 8200 \mathrm{yr}$ ago appear superimposed on this long-term cooling. Are these climate anomalies possibly reflected in the history of Tell Sabi Abyad?

Earlier, we reported (Akkermans et al. 2010) on our research, using a sequence from earlier excavations (called Operation I). Situated just a few hundreds of meters southeast of Operation III, the excavated sequence from Operation I is completely parallel to the sequence B reported here, and had been dated by ${ }^{14} \mathrm{C}$ as well, albeit much less intensively. The archaeological observations of these levels are the same as for sequence B. The conclusion remains the same: this sequence also shows continuous occupation of Tell Sabi Abyad throughout the duration of the 8.2 ka event.

\section{CONCLUSION}

At Tell Sabi Abyad, Syria, we obtained a robust chronology for the 7th to early 6th millennium BC, the Late Neolithic. The chronology was obtained using a large (145 samples) set of ${ }^{14} \mathrm{C}$ dates, analyzed by Bayesian statistics. This now represents the best-dated continuous chronology of this time range in the Near East. 
At this settlement, significant cultural change appears to have taken place around $6200 \mathrm{BC}$. The ${ }^{14} \mathrm{C}$ chronology now shows that this "cultural event" is contemporaneous with a well-known "climate event": the so-called $8.2 \mathrm{ka}$ event, a cold period observed in Greenland ice and other paleoclimate records. Summarizing, the climate event and societal change synchronize well.

Synchronicity does not imply causality, however. We need to be aware of the danger of determinism. Human societies do not simply roll and flow with the climate tide (deMenocal 2001; Rosen 2007); societies develop coping mechanisms and are often remarkably resilient. But we cannot ignore the compelling evidence for substantial cultural change and diversification during the time of climate change around 6200 BC. Fundamental transitions such as those observed at Tell Sabi Abyad must have required a strong impetus as they penetrated all realms of life at the Neolithic settlement and manifested themselves in decades. We believe that the $8.2 \mathrm{ka}$ climate event was among the forcing factors behind these changes.

However one reconstructs causality with regard to the effects of climate change, what is clear in any case is that our observations refute the deterministic "collapse of cultures" stance with which the archaeological record is currently replete. Prehistoric societies in the Near East were apparently able to adapt to variations in weather and climate. To the Late Neolithic inhabitants of Tell Sabi Abyad, drought represented a challenge that required the implementation of developed coping strategies.

\section{ACKNOWLEDGMENTS}

The project is funded by the Netherlands Organisation for Scientific Research (NWO), dossier 36062-040. Groningen BSc student Jan Boelens is thanked for his work on the Bayesian analysis.

\section{REFERENCES}

Akkad D. 2009. Escaping the drought. Syria Today 53: 23-9.

Akkermans PMMG, Schwartz GM. 2003. The Archaeology of Syria: From Complex Hunter-Gatherers to Early Urban Societies (ca. 16000-300 BC). Cambridge: Cambridge University Press. $486 \mathrm{p}$.

Akkermans PMMG, Cappers R, Cavallo C, Nieuwenhuyse O, Nilhamn B, Otte IN. 2006. Investigating the Early Pottery Neolithic of northern Syria: new evidence from Tell Sabi Abyad. American Journal of Archaeology 110(1):123-56.

Akkermans PMMG, van der Plicht J, Nieuwenhuyse O, Russell A, Kaneda A. 2009. Cultural transformation and the $8.2 \mathrm{ka}$ event in Upper Mesopotamia. Pre-modern climate change: causes and responses. Conference, Copenhagen (proceedings forthcoming).

Akkermans PMMG, van der Plicht J, Nieuwenhuyse O, Russell A, Kaneda A, Buitenhuis H. 2010. Weathering climate change in the Near East: dating and Neolithic adaptations 8200 years ago. Antiquity, online project gallery: http://antiquity.ac.uk/projgall/plicht325/.

Alley RB, Mayewski PA, Sowers T, Stuiver M, Taylor KC, Clark PU. 1997. Holocene climatic instability: a prominent, widespread event 8200 yr ago. Geology 25(6):483-6.

Balter M. 2010. In a cold snap, farmers turned to milk. Science 329(5998): 1465.

Barber DC, Dyke A, Hillaire-Marcel C, Jennings AE,
Andrews JT, Kerwin MW, Bilodeau G, McNeely R, Southon J, Morehead MD, Gagnon JM. 1999. Forcing of the cold event 8,200 years ago by catastrophic drainage of Laurentide lakes. Nature 400(6742):344-8.

Bayliss A. 2009. Rolling out revolution: using radiocarbon dating in archaeology. Radiocarbon 51(1):123-47.

Bronk Ramsey C. 2001. Development of the radiocarbon calibration program. Radiocarbon 43(2A):355-63.

Bronk Ramsey C. 2009. Bayesian analysis of radiocarbon dates. Radiocarbon 51(1):337-60.

Bruins HJ, Nijboer AJ, van der Plicht J. 2011. Iron Age Mediterranean chronology: a reply. Radiocarbon 53(1):199-220.

Chen H, Fleitman D, Edwards RL, Wang X, Cruz FW, Auler AS, Mangini A, Wang Y, Kong X, Burns SJ, Matter A. 2009. Timing and structure of the $8.2 \mathrm{kyr}$ B.P. event inferred from $\delta^{18} \mathrm{O}$ records of stalagmites from China, Oman, and Brazil. Geology 37(11):1007-10.

Clarke G, Leverington D, Teller J, Dyke A. 2003. Superlakes, megafloods and abrupt climate change. Science 301(5635):922-3.

deMenocal PB. 2001. Cultural responses to climate change during the Late Holocene. Science 292(5517): 667-73.

Ellison CRW, Chapman MR, Hall IR. 2006. Surface and deep ocean interactions during the cold climate event 8200 years ago. Science 312(5782):1929-32.

Evershed RP, Payne S, Sherratt AG, Copley MS, 
Coolidge J, Urem-Kotsu D, Kotsakis K, Ozdogan M, Özdoğan AE, Nieuwenhuyse O, Akkermans PMMG, Bailey D, Andeescu R-R, Campbell S, Farid S, Hodder I, Yalman N, Özbaşaran M, Erhan Biçakci E, Garfinkel Y, Levy T, Burton MM. 2008. Earliest date for milk use in the Near East and southeastern Europe linked to cattle herding. Nature 455(7212):528-31.

Hormes A, Blaauw M, Dahl SO, Nesje A, Possnert G. 2009. Radiocarbon wiggle-match dating of proglacial lake sediments-implications for the 8.2 ka event. Quaternary Geochronology 4(4):267-77.

Jansen E, Overpeck J, Briffa KR, Duplessy J-C, Joos F, Masson-Delmotte V, Olago D, Otto-Bliesner B, Peltier WR, Rahmstorf S, Ramesh R, Raynaud D, Rind D, Solomina O, Villalba R, Zhang D. 2007. Chapter 6: Paleoclimate. In: Climate Change 2007: The Physical Science Basis. Contribution of Working Group I to the Fourth Assessment Report of the Intergovernmental Panel on Climate Change. Cambridge: Cambridge University Press.

Kleiven HF, Kissel C, Laj C, Ninnemann US, Richter TO, Cortijo E. 2008. Reduced North Atlantic Deep Water coeval with the Glacial Lake Agassiz freshwater outburst. Science 319(5859):60-4.

Kobashi T, Severinghaus JP, Brook EJ, Barnola JM, Grachev AM. 2007. Precise timing and characterization of abrupt climate change 8200 years ago from air trapped in polar ice. Quaternary Science Reviews 26(9-10):1212-22.

Mook WG, Streurman HJ. 1983. Physical and chemical aspects of radiocarbon dating. In: First Symposium on ${ }^{14} \mathrm{C}$ and Archaeology, Groningen. PACT 8:31-55.

Morrill C, Jacobsen RM. 2005. How widespread were climate anomalies 8200 years ago? Geophysical Research Letters 32: L19701, doi:10.1029/ 2005GL023536.

Nicolussi K, Kaufmann M, Melvin TM, van der Plicht J, Schiessling P, Thurner A. 2009. A 9111 year long conifer tree-ring chronology for the European Alps: a base for environmental and climatic investigations. The Holocene 19(6):909-20.

Nieuwenhuyse O, Akkermans PMMG, van der Plicht J. 2010. Not so coarse, nor always plain - the earliest pottery of Syria. Antiquity 84:71-85.

Reimer PJ, Baillie MGL, Bard E, Bayliss A, Beck JW, Blackwell PG, Bronk Ramsey C, Buck CE, Burr GS, Edwards RL, Friedrich M, Grootes PM, Guilderson TP, Hajdas I, Heaton TJ, Hogg AG, Hughen KA, Kaiser KF, Kromer B, McCormac FG, Manning SW, Reimer RW, Richards DA, Southon JR, Talamo S, Turney CSM, van der Plicht J, Weyhenmeyer CE. 2009. IntCa109 and Marine09 radiocarbon age calibration curves, $0-50,000$ years cal BP. Radiocarbon 51(4): 1111-50.

Rohling EJ, Pälike H. 2005. Centennial-scale climate cooling with a sudden cold event around 8,200 years ago. Science 434(7036):975-9.
Rosen AM. 2007. Civilizing Climate: Social Responses to Climate Change in the Ancient Near East. Lanham: AltaMira Press. 224 p.

Russell A. 2010. Retracing the steppes: a zooarchaeological analysis of changing subsistence patterns in the Late Neolithic at Tell Sabi Abyad, northern Syria, 6900 to $5900 \mathrm{BC}$ [PhD thesis]. Leiden University.

Schmitt GA, Jansen E. 2006. The 8.2 kyr event. PAGES/ CLIVAR Workshop Report. PAGES News 14:28-9.

Schwartz P, Randall D. 2003. An abrupt climate change scenario and its implications for United States national security. Available online: http://www.ems.org/climate/pentagon_climate_change.html\#report.

Spurk M, Leuschner HH, Baillie MGL, Briffa KR, Friedrich M. 2002. Depositional frequency of German subfossil oaks: climatically and non-climatically induced fluctuations in the Holocene. The Holocene 12(6):707-15.

Thomas ER, Wolff EW, Mulvaney R, Steffensen JP, Johnsen SJ, Arrowsmith C, White JCW, Vaighn B, Popp T. 2007. The $8.2 \mathrm{ka}$ event from Greenland ice cores. Quaternary Science Reviews 26(1-2):70-81.

van der Plicht J, Bruins HJ, Nijboer AJ. 2009. The Iron Age around the Mediterranean: a high chronology perspective from the Groningen radiocarbon database. Radiocarbon 51(1):213-42.

van Strydonck M, Nelson DE, Crombé P, Bronk Ramsey C, Scott EM, van der Plicht J, Hedges REM. 1999. What's in a ${ }^{14} \mathrm{C}$ date. In: Evin J, Oberlin C, Daugas JP, Salles JF, editors. Radiocarbon and Archaeology: Proceedings of the 3rd International Symposium. Lyon, 1998. p 433-40.

von Grafenstein U, Erlenkeuser H, Müller J, Jouzel J, Johnsen J. 1998. The cold event 8200 years ago documented in oxygen isotope records of precipitation in Europe and Greenland. Climate Dynamics 14(2):7381.

Weiss H. 2003. The $8.2 \mathrm{ka}$ abrupt climate change event and the origins of irrigation agriculture and surplus agro-production in Mesopotamia. Eos Transactions AGU 84/(46). Fall Meeting Supplement, abstract PP22C-01.

Weiss H, Bradley RS. 2001. What drives societal collapse? Science 291(5504):609-10.

Weninger B, Alram-Stern E, Bauer E, Clare L, Danzeglocke U, Jöris O, Kubatzki C, Rollefson G, Todorova H, van Andel T. 2006. Climate forcing due to the 8200 cal yr BP event observed at Early Neolithic sites in the eastern Mediterranean. Quaternary Research 66(3): 401-20.

Wiersma AP. 2008. Character and causes of the $8.2 \mathrm{ka} \mathrm{cli-}$ mate event [PhD thesis]. Amsterdam: Free University of Amsterdam.

Wiersma AP, Renssen H. 2006. Model-data comparison for the $8.2 \mathrm{ka}$ BP event: confirmation of a forcing mechanism by catastrophic drainage of Laurentide lakes. Quaternary Science Reviews 25(1-2):63-88. 


\section{APPENDIX}

Date list of ${ }^{14} \mathrm{C}$ samples of charcoal and other charred materials for Tell Sabi Abyad. It shows the laboratory code (GrA: Groningen AMS, GrN: Groningen conventional), dated material, prehistoric level, sample context, ${ }^{14} \mathrm{C}$ age and error $(1 \sigma)$, calibrated age range $(1 \sigma)$, sample organic content $\left(\mathrm{C}_{\mathrm{v}}\right.$ in \%), stable carbon isotope ratio $\left(\delta^{13} \mathrm{C}\right.$ in \%o), and archaeological identification number.

Appendix Date list of ${ }^{14} \mathrm{C}$ samples of charcoal and other charred materials for Tell Sabi Abyad.

\begin{tabular}{|c|c|c|c|c|c|c|c|c|c|}
\hline Lab code & Material & Level & Context & $\begin{array}{l}{ }^{14} \mathrm{C} \\
\mathrm{BP}\end{array}$ & $1 \sigma$ & $\begin{array}{l}\delta^{13} \mathrm{C} \\
\% \text { o }\end{array}$ & $\begin{array}{l}\mathrm{C}_{\mathrm{v}} \\
\%\end{array}$ & cal BC $(1 \sigma)$ & Sample ID \\
\hline GrA-33001 & Charcoal & A12 & pit fill GO & 7955 & 35 & -23.99 & 62 & $7030-6770(68.2 \%)$ & SN05-333 \\
\hline GrA-33002 & Charcoal & A12 & $\begin{array}{l}\text { wall fills FV, } \\
\text { FT, FW, FF, } \\
\text { GJ, GH, GF }\end{array}$ & 8005 & 35 & -23.95 & 63 & $7050-6830(68.2 \%)$ & SN05-334 \\
\hline GrA-33007 & Charcoal & A12 & hearth fill FX & 8040 & 35 & -22.65 & 60 & $7070-6840(68.2 \%)$ & SN05-348 \\
\hline 2821 & Charcoal & A12 & hearth fill FX & 8010 & 45 & -23.42 & 61 & 705 & $\mathrm{SN}$ \\
\hline GrA-33006 & Charcoal & A11 & hearth fill FU & 7930 & 35 & -22.56 & 61 & 700 & $\mathrm{SNC}$ \\
\hline GrA-33009 & Charcoal & A11 & hearth fill FU & 7990 & 35 & -19.46 & 53 & 7045-6830 (68.2\%) & SN05-332 \\
\hline GrA-42817 & Charcoal & A11 & hearth fill FK & 7890 & 50 & -24.06 & 58 & $\begin{array}{l}6900-6890(1.0 \%) \\
6825-6645(67.2 \%)\end{array}$ & SN05-146 \\
\hline GrA & al & 11 & $11 \mathrm{FJ}$ & 7995 & 45 & -24.10 & 58 & $7050-6825(68.2 \%)$ & 60 \\
\hline GrA-42820 & Charcoal & A11 & ash & 8615 & 50 & -25.23 & 51 & $7580(68.2 \%)$ & 480 \\
\hline $\mathrm{GrA}-$ & Charcoal & A10 & hearth fill FD & 7970 & 45 & -18.22 & 57 & $7035-6820(68.2 \%)$ & SN0 \\
\hline GrA-42811 & Charcoal & A10 & hearth fill FA & 7925 & 45 & -25.22 & 41 & 7020-6690 (68.2\%) & SN05-091 \\
\hline GrA-42812 & Charcoal & A10 & hearth fill EZ & 7985 & 45 & -22.17 & 53 & $\begin{array}{l}7045-6905(46.8 \%) \\
6890-6825(21.4 \%)\end{array}$ & SN05-096 \\
\hline 13 & & 10 & FB & 7910 & 45 & -24.11 & 57 & $6985-6655(68.2 \%)$ & 122 \\
\hline 15 & Chat & A10 & hea & 7940 & 45 & -24.62 & 58 & 702 & 214 \\
\hline GrA-32059 & Charcoal & A10 & & 7930 & 45 & -25.16 & 60 & & -196 \\
\hline GrA-42801 & Charcoal & A9 & fill ED & 7705 & 45 & -23.16 & 58 & 659 & SN05-009 \\
\hline 802 & Char & A9 & EH & 8270 & 45 & -25.95 & 54 & 74 & 021 \\
\hline 304 & $\mathrm{Ch}$ & A9 & $E M$ & 7795 & 45 & -24.34 & 6 & & \\
\hline 306 & Cha & A9 & $\mathrm{ET}$ & 7820 & 45 & -23.40 & 60 & & \\
\hline 807 & Charcoal & A9 & $1 \mathrm{CC}$ & 7740 & 45 & -25.20 & 57 & 66 & 09 \\
\hline 785 & Charcoal & A8 & $\mathrm{CB}$ & 7725 & 45 & -22.02 & 59 & $5(68.2 \%)$ & -105 \\
\hline 2786 & Cha & A8 & $\mathrm{BK}$ & 7715 & 45 & -23.52 & 63 & $95(68.2 \%)$ & -107 \\
\hline GrA-42787 & $\begin{array}{l}\text { Charred } \\
\text { seeds }\end{array}$ & A8 & over & 7835 & 45 & -23.67 & 36 & $\begin{array}{l}6735-6725(2.9 \%) \\
6700-6595(65.3 \%)\end{array}$ & -128 \\
\hline $\mathrm{Gr}$ & Charcoal & A8 & DP & 7760 & 45 & 80 & 61 & $\begin{array}{l}-6565(57.9 \%) \\
-6525(10.3 \%)\end{array}$ & 79 \\
\hline GrA-42797 & Charcoal & A8 & hea & 7775 & 45 & .01 & 60 & $\begin{array}{l}6650-6565(61.1 \%) \\
6545-6530(7.1 \%)\end{array}$ & 08 \\
\hline GrA-42800 & Charcoal & A8 & hearth fill DZ & 7780 & 45 & -24.21 & 57 & $\begin{array}{l}6655-6565(62.5 \%) \\
6545-6530 \\
(5.7 \%)\end{array}$ & 34 \\
\hline 50 & & A 8 & & 7715 & 45 & -25.68 & 48 & $6595-6495(68.2 \%)$ & \\
\hline 875 & Charcoal & A7 & $1 \mathrm{DD}$ & 7690 & 45 & -19.86 & 67 & $\%)$ & 130 \\
\hline 1876 & Charcoal & A7 & I DB & 7700 & 50 & -23.01 & 68 & $0(68.2 \%)$ & SN04-136 \\
\hline GrA-31877 & Charcoal & A7 & fill DL & 7695 & 45 & -24.38 & 52 & $6590-6475(68.2 \%)$ & SN04-180 \\
\hline GrA-32047 & Charcoal & A7 & pit fill DS & 7640 & 45 & -22.60 & 57 & $\begin{array}{ll}6560-6550 & (4.3 \%) \\
6510-6435 & (63.9 \%)\end{array}$ & SN04-114 \\
\hline GrA-32048 & Charcoal & A7 & & 7705 & 45 & -24.82 & 59 & $6595-6480(68.2 \%)$ & 116 \\
\hline GrA-32049 & Charcoal & A7 & DU & 7735 & 45 & -24.11 & 60 & $6610-6500(68.2 \%)$ & SN04-118 \\
\hline GrA-42781 & Charcoal & A7 & hearth fill $\mathrm{N}$ & 7680 & 45 & -25.08 & 60 & $\begin{array}{l}6570-6540(17.7 \%) \\
6535-6465(50.5 \%)\end{array}$ & SN04-078 \\
\hline GrA-42788 & Char & A7 & ill CZ & 7710 & 40 & -23.54 & 66 & $6595-6500(68.2 \%)$ & SN05-185 \\
\hline GrA-42790 & Charcoal & A7 & fill DE & 7710 & 45 & -22.92 & 61 & 6595-6495 (68.2\%) & SN05-219 \\
\hline GrA-42791 & Charcoal & A7 & hearth fill CV & 7665 & 45 & -23.16 & 60 & $\begin{array}{l}6570-6545(13.1 \%) \\
6530-6455(55.1 \%)\end{array}$ & SN05-231 \\
\hline
\end{tabular}


Appendix Date list of ${ }^{14} \mathrm{C}$ samples of charcoal and other charred materials for Tell Sabi Abyad. (Continued)

\begin{tabular}{|c|c|c|c|c|c|c|c|c|c|}
\hline Lab code & Material & Level & Context & $\begin{array}{l}{ }^{14} \mathrm{C} \\
\mathrm{BP}\end{array}$ & $1 \sigma$ & $\begin{array}{l}\delta^{13} \mathrm{C} \\
\% 0\end{array}$ & $\begin{array}{l}\mathrm{C}_{\mathrm{v}} \\
\%\end{array}$ & cal BC $(1 \sigma)$ & Sample ID \\
\hline GrA-42795 & Charcoal & A7 & hearth fill ER & 7725 & 45 & -25.29 & 60 & $6600-6495(68.2 \%)$ & SN05-324 \\
\hline GrA-42796 & Charcoal & A7 & hearth fill DH & 7635 & 45 & -24.79 & 46 & $\begin{array}{l}6560-6550(2.3 \%) \\
6510-6435(65.9 \%)\end{array}$ & SN04-143 \\
\hline GrA-42798 & Charcoal & A7 & hearth fill DY & 7700 & 45 & -24.73 & 60 & $6590-6480(68.2 \%)$ & SN05-225 \\
\hline GrN-29713 & Charcoal & A7 & hearth fill DF & 7765 & 30 & -23.89 & 67 & $\begin{array}{l}6645-6570(64.9 \%) \\
6540-6530(3.3 \%)\end{array}$ & SN04-156 \\
\hline GrA-32052 & Charcoal & A6 & $\begin{array}{l}\text { open area un- } \\
\text { der floor CO }\end{array}$ & 8170 & 80 & -22.59 & 60 & $\begin{array}{l}7305-7215(23.5 \%) \\
7200-7065(44.7 \%)\end{array}$ & $\mathrm{SN}$ \\
\hline GrA-42782 & Charcoal & A6 & hearth fill CP & 7535 & 45 & -23.49 & 59 & $6450-6380(68.2 \%)$ & SN05-129 \\
\hline GrN-29706 & Charcoal & A6 & hear & 7570 & 60 & -25.14 & 64 & $\%)$ & 076 \\
\hline 2051 & Charcoal & A5 & $\mathrm{h}$ fill AZ & 7625 & 45 & -22.54 & 57 & $\%)$ & 153 \\
\hline GrA-32053 & Charcoal & A5 & hearth fill BB & 7545 & 45 & -24.54 & 58 & $390(68.2 \%)$ & SN0 \\
\hline 2056 & Charcoal & A5 & pit fill CL & 7760 & 50 & -19.33 & 52 & $510(68.2 \%)$ & SN04-028 \\
\hline GrA-32062 & Charcoal & A5 & bin fill $\mathrm{BO}$ & 7740 & 45 & -19.13 & 60 & $6505(68.2 \%)$ & SN04-230 \\
\hline GrA-42775 & Charcoal & A5 & bin fill \#217 & 7725 & 45 & -20.86 & 50 & $6600-6495(68.2 \%)$ & SN04-102 \\
\hline GrA-42776 & Charcoal & A5 & bin fill AU & 7595 & 45 & -22.47 & 56 & 648 & SN04-106 \\
\hline GrA-42780 & Charcoal & A5 & hearth fill GP & 7655 & 45 & -23.29 & 64 & $\begin{array}{l}6570-6545(10.7 \%) \\
6530-6450(57.5 \%)\end{array}$ & SN08-496 \\
\hline GrA-42889 & $\mathrm{al}$ & A5 & $\mathrm{D}$ & 7555 & 45 & 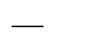 & - & $6460-6395(68.2 \%)$ & $359 b$ \\
\hline GrA-24219 & Charcoal & A4 & room fill & 7570 & 50 & - & - & $6465-6400$ & SN02-117 \\
\hline GrA-24248 & Charcoal & A4 & $\begin{array}{l}\text { oven fill AJ, } \\
\text { on floor AN }\end{array}$ & 7720 & 50 & -25.19 & 58 & 660 & SNO \\
\hline GrA-26877 & Chr & A4 & $1 \mathrm{AC}$ & 27,790 & 370 & 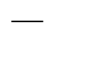 & - & $\begin{array}{r}30,4 \\
\quad(6\end{array}$ & SN03-127 \\
\hline GrA- & Cha & A4 & roo & 7475 & 45 & - & - & $\begin{array}{l}6415-6345(40.0 \%) \\
6315-6260(28.2 \%)\end{array}$ & 107 \\
\hline GrA-26928 & oal & A4 & & 7525 & 45 & - & - & $6450-6370(68.2 \%)$ & 124 \\
\hline GrA-32058 & $\begin{array}{l}\text { Cha } \\
\text { grai }\end{array}$ & A4 & pit & 7495 & 45 & -23.28 & 58 & $\begin{array}{l}(54.3 \%) \\
(13.9 \%)\end{array}$ & -012 \\
\hline GrA-32063 & Charcoal & A4 & bin & 12,230 & 60 & 94 & 66 & 2,020 & SNO \\
\hline 2728 & bal & A4 & & 7540 & 40 & -24.33 & 62 & & 12 \\
\hline 2729 & Char & A4 & DP & 7540 & 40 & -25.79 & 58 & $\%)$ & -017 \\
\hline GrA-42730 & Charcoal & A4 & hear & 7460 & 40 & -25.51 & 65 & $\begin{array}{l}0(33.3 \%) \\
5(34.9 \%)\end{array}$ & SN08-066 \\
\hline GrA- & oal & 4 & $\mathrm{FT}$ & 7475 & 40 & 02 & 62 & $\begin{array}{l}0(40.3 \%) \\
0(27.9 \%)\end{array}$ & 64 \\
\hline $\mathrm{Gr}$ & Charcoal & 14 & FL & 7445 & 40 & 60 & 63 & $\begin{array}{l}0(28.4 \%) \\
5(39.8 \%)\end{array}$ & 169 \\
\hline GrA-42764 & Charcoal & A4 & hea & 7505 & 40 & 49 & 63 & $\begin{array}{l}360(60.9 \%) \\
270(7.3 \%)\end{array}$ & 383 \\
\hline GrA-42766 & Charcoal & A4 & $1 \mathrm{GE}$ & 18,850 & 80 & 27.40 & 60 & 20,225 & SN08-314 \\
\hline GrA-42768 & Charcoal & A4 & hearth fill HT & 7465 & 40 & -23.62 & 58 & $\begin{array}{l}6400-6340(34.7 \%) \\
6315-6260(33.5 \%)\end{array}$ & 501 \\
\hline GrA-42778 & Charcoal & A4 & hearth fill DJ & 7475 & 40 & 23.21 & 63 & $\begin{array}{l}6415-6350(40.3 \%) \\
6315-6260(27.9 \%)\end{array}$ & SN08-372 \\
\hline GrA-42901 & Charcoal & A4 & $\begin{array}{l}\text { hearth fill } \\
\text { DA/DC/DE }\end{array}$ & 7425 & 50 & - & - & $\begin{array}{l}6370-6280(50.2 \%) \\
6275-6240(18.0 \%)\end{array}$ & SN08-499b \\
\hline GrN-29714 & Charcoal & A4 & oven fill ES & 7680 & 30 & -23.70 & 69 & $\begin{array}{l}6570-6545(15.5 \%) \\
6530-6465(52.7 \%)\end{array}$ & SN04-158 \\
\hline GrA-42481 & $\begin{array}{l}\text { Charred } \\
\text { seeds }\end{array}$ & A3 & room fill & 7500 & 45 & - & - & $\begin{array}{l}6435-6355(56.6 \%) \\
6295-6265(11.6 \%)\end{array}$ & SN07-613 \\
\hline GrA-42723 & Charcoal & A3 & room fill & 7450 & 40 & -25.60 & 63 & $\begin{array}{l}6385-6335(29.5 \%) \\
6320-6255(38.7 \%)\end{array}$ & SN07-597 \\
\hline
\end{tabular}


Appendix Date list of ${ }^{14} \mathrm{C}$ samples of charcoal and other charred materials for Tell Sabi Abyad. (Continued)

\begin{tabular}{|c|c|c|c|c|c|c|c|c|c|}
\hline Lab code & Material & Level & Context & $\begin{array}{l}{ }^{14} \mathrm{C} \\
\mathrm{BP}\end{array}$ & $1 \sigma$ & $\begin{array}{l}\delta^{13} \mathrm{C} \\
\% 0\end{array}$ & $\begin{array}{l}\mathrm{C}_{\mathrm{v}} \\
\%\end{array}$ & cal BC $(1 \sigma)$ & Sample ID \\
\hline GrA-42724 & $\begin{array}{l}\text { Charred } \\
\text { seeds }\end{array}$ & A3 & $\begin{array}{l}\text { room fill, } \\
\text { filled with } \\
\text { burnt soil }\end{array}$ & 7435 & 40 & -22.55 & 62 & $6370-6250(68.2 \%)$ & SN08-323 \\
\hline GrA-42727 & Charcoal & A3 & room fill & 7455 & 40 & -23.35 & 67 & $\begin{array}{l}6395-6335(31.9 \%) \\
6315-6225(36.3 \%)\end{array}$ & SN07-601 \\
\hline GrN-29719 & Seeds & A3 & $\begin{array}{l}\text { room fill AI } \\
\text { with burned } \\
\text { grain }\end{array}$ & 7485 & 15 & -23.44 & 69 & $6415-6365(68.2 \%)$ & SN04-221 \\
\hline GrN-29720 & Seeds & A3 & $\begin{array}{l}\text { room fill AI } \\
\text { with burned } \\
\text { grain }\end{array}$ & 7450 & 15 & -23.47 & 68 & $\begin{array}{l}6380-6350(23.8 \%) \\
6315-6260(44.4 \%)\end{array}$ & SN04-222 \\
\hline GrA-32046 & $\begin{array}{l}\text { Charred } \\
\text { seeds }\end{array}$ & A2 & open area & 7440 & 45 & -24.79 & 60 & $\begin{array}{l}6380-6325(28.1 \%) \\
6320-6250(40.1 \%)\end{array}$ & SN04-067 \\
\hline GrA-42463 & Charcoal & A2 & oven fill BN & 7535 & 45 & -23.82 & 61 & $6450-6380(68.2 \%)$ & SN08-016 \\
\hline GrA-42465 & Charcoal & A2 & hearth fill BQ & 7510 & 45 & -25.50 & 65 & $\begin{array}{l}6440-6360(61.0 \%) \\
6290-6270(7.2 \%)\end{array}$ & SN0 \\
\hline GrA-42466 & Charcoal & A2 & hearth fill BR & 7675 & 45 & -24.78 & 57 & $\begin{array}{l}6570-6540(15.9 \%) \\
6535-6465(52.3 \%)\end{array}$ & SN08-104 \\
\hline GrA- 42480 & Charcoal & A2 & $\begin{array}{l}\text { oven fill FL } \\
\text { inside tholos }\end{array}$ & 7425 & 45 & -22.74 & 59 & $\begin{array}{l}6365-6280(50.5 \%) \\
6275-6240(17.7 \%)\end{array}$ & SN07-598 \\
\hline GrA-42489 & Charcoal & A2 & oven fill FL & 7475 & 45 & -15.59 & 55 & $\begin{array}{l}6415-6345(40.0 \%) \\
6315-6260(28.2 \%)\end{array}$ & SN08-008 \\
\hline GrA-42490 & Charcoal & A2 & bin fill BS & 7395 & 45 & -24.38 & 66 & $\begin{array}{l}6360-6285(40.3 \%) \\
6270-6225(27.9 \%)\end{array}$ & SN08-131 \\
\hline GrA-42491 & Charcoal & $\mathrm{A} 2$ & hearth fill EW & 7400 & 45 & -22.21 & 62 & $\begin{array}{l}6365-6285(42.1 \%) \\
6275-6225(26.1 \%)\end{array}$ & SN08-153 \\
\hline GrA-42492 & Charcoal & A2 & hearth fill CD & 7380 & 45 & -24.13 & 66 & $\begin{array}{l}6365-6285(34.9 \%) \\
6275-6215(33.3 \%)\end{array}$ & SN08-188 \\
\hline GrA-42494 & Charcoal & $\mathrm{A} 2$ & room fill & 7425 & 45 & -26.73 & 65 & $\begin{array}{l}6365-6280(50.5 \%) \\
6275-6240(17.7 \%)\end{array}$ & SN08-378 \\
\hline GrA-42495 & Charcoal & A2 & hearth fill DU & 7465 & 45 & -26.35 & 60 & $\begin{array}{l}6400-6340(35.0 \%) \\
6315-6255(33.2 \%)\end{array}$ & SN08-477 \\
\hline GrA-42496 & Charcoal & A2 & oven fill DW & 7470 & 45 & -23.79 & 56 & $\begin{array}{l}6405-6340(36.7 \%) \\
6315-6255(31.5 \%)\end{array}$ & SN08-479 \\
\hline GrA-42499 & Charcoal & A2 & oven fill DX & 7445 & 45 & -24.87 & 61 & $\begin{array}{l}6380-6330(28.8 \%) \\
6320-6250(39.4 \%)\end{array}$ & SN08-487 \\
\hline GrA-42500 & Charcoal & A2 & oven fill EF & 7450 & 45 & -23.10 & 62 & $\begin{array}{l}6385-6330(30.8 \%) \\
6320-6250(37.4 \%)\end{array}$ & SN08-495 \\
\hline GrA-42722 & Charcoal & A2 & $\begin{array}{l}\text { room fill FZ } \\
\text { with burnt } \\
\text { material }\end{array}$ & 7605 & 40 & - & - & $6475-6430(68.2 \%)$ & SN08-300 \\
\hline GrA-42900 & Charcoal & A2 & open area & 7475 & 50 & -24.95 & 58 & $\begin{array}{l}6415-6345(39.9 \%) \\
6315-6220(28.3 \%)\end{array}$ & SN08-326b \\
\hline GrA-32997 & Charcoal & A1 & $\begin{array}{l}\text { room fill (tho- } \\
\text { los), under } \\
\text { floor AJ }\end{array}$ & 7440 & 35 & -21.35 & 62 & $\begin{array}{l}6375-6330(25.9 \%) \\
6320-6255(42.3 \%)\end{array}$ & SN05-298 \\
\hline GrA-33003 & Charcoal & A1 & $\begin{array}{l}\text { room fill (tho- } \\
\text { los) under pit } \\
\text { EI and oven X }\end{array}$ & 7425 & 35 & -25.09 & 64 & $\begin{array}{l}6365-6285(51.2 \%) \\
6275-6245(17.0 \%)\end{array}$ & SN05-336 \\
\hline GrA-42334 & Charcoal & A1 & oven fill $\mathrm{N}$ & 7420 & 45 & -24.45 & 63 & $\begin{array}{l}6365-6285(48.2 \%) \\
6275-6240(20.0 \%)\end{array}$ & SN07-027 \\
\hline GrA-42337 & Charcoal & A1 & hearth fill KL & 7445 & 45 & -26.80 & 55 & $\begin{array}{l}6380-6330(28.8 \%) \\
6320-6250(39.4 \%)\end{array}$ & SN08-096 \\
\hline GrA-42338 & Charcoal & A1 & $\begin{array}{l}\text { oven fill X in- } \\
\text { side tholos }\end{array}$ & 7380 & 45 & -26.80 & 55 & $\begin{array}{l}6365-6285(34.9 \%) \\
6275-6215(33.3 \%)\end{array}$ & SN05-059 \\
\hline GrA-42340 & Charcoal & A1 & room fill & 7400 & 45 & -25.21 & 56 & $\begin{array}{l}6365-6285(42.1 \%) \\
6275-6225(26.1 \%)\end{array}$ & SN05-253 \\
\hline
\end{tabular}


Appendix Date list of ${ }^{14} \mathrm{C}$ samples of charcoal and other charred materials for Tell Sabi Abyad. (Continued)

\begin{tabular}{|c|c|c|c|c|c|c|c|c|c|}
\hline Lab code & Material & Level & Context & $\begin{array}{l}{ }^{14} \mathrm{C} \\
\mathrm{BP}\end{array}$ & $1 \sigma$ & $\begin{array}{l}\delta^{13} \mathrm{C} \\
\% 0\end{array}$ & $\begin{array}{l}\mathrm{C}_{\mathrm{v}} \\
\%\end{array}$ & cal BC $(1 \sigma)$ & Sample ID \\
\hline GrA-42342 & Charcoal & A1 & $\begin{array}{l}\text { hearth fill EJ } \\
\text { (tholos) un- } \\
\text { der floor EE }\end{array}$ & 7475 & 45 & -24.38 & 56 & $\begin{array}{l}6415-6345(40.0 \%) \\
6315-6260(28.2 \%)\end{array}$ & SN05-331 \\
\hline GrA-42452 & Charcoal & A1 & hearth fill AU & 7600 & 50 & -23.39 & 57 & $6485-6415(68.2 \%)$ & SN07-198 \\
\hline GrA-42453 & Charcoal & A1 & room fill & 7440 & 45 & -23.36 & 60 & $\begin{array}{l}6380-6325(28.1 \%) \\
6320-6250(40.1 \%)\end{array}$ & SN07-226 \\
\hline GrA-42455 & Charcoal & A1 & oven fill CW & 7370 & 45 & -24.04 & 61 & $6360-6110(68.2 \%)$ & SN07-231 \\
\hline GrA-42456 & Charcoal & A1 & oven fill V & 7445 & 45 & -22.68 & 59 & $\begin{array}{l}6380-6330(28.8 \%) \\
6320-6250(39.4 \%)\end{array}$ & SN07-353 \\
\hline GrA-42457 & Charcoal & A1 & hearth fill AV & 7480 & 45 & -24.05 & 60 & $\begin{array}{l}6420-6350(42.0 \%) \\
6315-6260(26.2 \%)\end{array}$ & SN07-366 \\
\hline GrA-42459 & Charcoal & A1 & bin fill DA & 7465 & 45 & -22.74 & 62 & $\begin{array}{l}6400-6340(35.0 \%) \\
6315-6255(33.2 \%)\end{array}$ & SN07-463 \\
\hline GrA-42461 & Charcoal & A1 & bin fill $\mathrm{CN}$ & 6930 & 45 & -22.74 & 62 & $\begin{array}{l}5870-5865(2.1 \%) \\
5850-5740(66.1 \%)\end{array}$ & SN07-465 \\
\hline GrA-42462 & Charcoal & A1 & $\begin{array}{l}\text { hearth fill in- } \\
\text { side tholos }\end{array}$ & 7460 & 45 & -23.36 & 62 & $\begin{array}{l}6395-6335(33.7 \%) \\
6315-6255(34.5 \%)\end{array}$ & SN07-607 \\
\hline GrA-42467 & Charcoal & A1 & oven fill HJ & 7475 & 45 & -24.59 & 65 & $\begin{array}{l}6415-6345(40.0 \%) \\
6315-6260(28.2 \%)\end{array}$ & SN08-304 \\
\hline GrA-42468 & Charcoal & A1 & hearth fill AU & 7520 & 45 & -25.04 & 57 & $\begin{array}{l}6445-6365(66.5 \%) \\
6280-6275(1.7 \%)\end{array}$ & SN08-364 \\
\hline GrA-42470 & Charcoal & A1 & hearth fill DO & 7460 & 45 & -23.75 & 61 & $\begin{array}{l}6395-6335(33.7 \%) \\
6315-6255(34.5 \%)\end{array}$ & 391 \\
\hline GrA-42472 & Charcoal & A1 & fill DN & 7165 & 45 & -24.92 & 61 & $6065-6000(68.2 \%)$ & SN08-393 \\
\hline GrA-42473 & Charcoal & A1 & hearth fill AV & 7475 & 45 & -24.01 & 60 & $\begin{array}{l}6415-6345(40.0 \%) \\
6315-6260(28.2 \%)\end{array}$ & SN08-485 \\
\hline GrA-42476 & Cha & A1 & roo & 7490 & 45 & -24.58 & 62 & $6430-6265(68.2 \%)$ & -518 \\
\hline GrA-42477 & Charcoal & A1 & hearth fill DF & 7415 & 45 & -23.68 & 64 & $\begin{array}{l}6365-6285(46.3 \%) \\
6275-6235(21.9 \%)\end{array}$ & SN04-080 \\
\hline GrA-42479 & Charcoal & A1 & room fill & 455 & 45 & 66 & 65 & $\begin{array}{l}6395-6335(32.3 \%) \\
6315-6255(35.9 \%)\end{array}$ & 249 \\
\hline GrA-42866 & Charcoal & A1 & hearth fill CJ & 450 & 45 & .86 & 60 & $\begin{array}{l}6385-6330(30.8 \%) \\
6320-6250(37.4 \%)\end{array}$ & SN07-356 \\
\hline GrN-28851 & $\begin{array}{l}\text { Charred } \\
\text { grains }\end{array}$ & A1 & $\begin{array}{l}\text { room fill (up- } \\
\text { per level) }\end{array}$ & 7400 & 25 & - & - & $\begin{array}{l}6355-6310(36.7 \%) \\
6265-6230(31.5 \%)\end{array}$ & SN03-010 \\
\hline GrN-28855 & $\begin{array}{l}\text { Charred } \\
\text { grains }\end{array}$ & A1 & $\begin{array}{l}\text { room fill, on } \\
\text { floor level? }\end{array}$ & 7360 & 25 & - & - & $6330-6115(68.2 \%)$ & SN03-077 \\
\hline GrA-42333 & Charcoal & B8 & oven fill $\mathrm{R}$ & 7230 & 45 & -23.70 & 64 & $6205-6025(68.2 \%)$ & SN07-018 \\
\hline GrA-42336 & Charcoal & B8 & bin fill $\mathrm{P}$ & 6880 & 40 & -23.83 & 63 & $5805-5720(68.2 \%)$ & SN07-046 \\
\hline GrA-42343 & Charcoal & B8 & bin fill $\mathrm{AX}$ & 7230 & 45 & -23.43 & 60 & $6205-6025(68.2 \%)$ & SN07-101 \\
\hline GrA-42344 & Charcoal & $\mathrm{B} 8$ & vessel fill BM & 7230 & 45 & -23.31 & 59 & $6205-6025(68.2 \%)$ & SN07-104 \\
\hline GrA-42346 & Charcoal & $\mathrm{B} 8$ & bin fill $A X$ & 7250 & 45 & -23.87 & 60 & $\begin{array}{l}6210-6135(38.1 \%) \\
6110-6060(30.1 \%)\end{array}$ & SN07-109 \\
\hline GrA-42347 & Cha & B8 & IIII BK & 7360 & 45 & -22.96 & 59 & $6350-6100(68.2 \%)$ & SN07-110 \\
\hline GrA-42486 & Charcoal & B8 & $\begin{array}{l}\text { vessel (P07- } \\
048) \text { fill in } \\
\text { Burial } 32\end{array}$ & 7250 & 45 & -23.51 & 60 & $\begin{array}{l}6210-6135(38.1 \%) \\
6110-6060(30.1 \%)\end{array}$ & SN07-195 \\
\hline GrA-42862 & Charcoal & B8 & oven fill BB & 7360 & 45 & -24.06 & 57 & $6350-6100(68.2 \%)$ & SN07-230 \\
\hline GrA-42864 & Charcoal & $\mathrm{B} 8$ & oven fill BM & 7365 & 45 & -23.25 & 58 & $6355-6105(68.2 \%)$ & SN07-275 \\
\hline GrA-42865 & Charcoal & $\mathrm{B} 8$ & hearth fill BE & 7315 & 45 & -13.33 & 42 & $\begin{array}{l}6230-6200(16.3 \%) \\
6195-6100(51.9 \%)\end{array}$ & SN07-278 \\
\hline GrA-42868 & Charcoal & B8 & oven fill BP & 7320 & 45 & -24.63 & 59 & $\begin{array}{l}6230-6200(17.2 \%) \\
6195-6100(51.0 \%)\end{array}$ & SN07-473 \\
\hline GrA-42890 & Charcoal & $\mathrm{B} 8$ & oven fill BZ & 7305 & 40 & -26.64 & 63 & $\begin{array}{l}6225-6200(13.3 \%) \\
6195-6100(54.9 \%)\end{array}$ & SN07-518 \\
\hline
\end{tabular}


Appendix Date list of ${ }^{14} \mathrm{C}$ samples of charcoal and other charred materials for Tell Sabi Abyad. (Continued)

\begin{tabular}{|c|c|c|c|c|c|c|c|c|c|}
\hline Lab code & Material & Level & Context & $\begin{array}{l}{ }^{14} \mathrm{C} \\
\mathrm{BP}\end{array}$ & $1 \sigma$ & $\begin{array}{l}\delta^{13} \mathrm{C} \\
\% 0\end{array}$ & $\begin{array}{l}\mathrm{C}_{\mathrm{v}} \\
\%\end{array}$ & cal BC $(1 \sigma)$ & Sample ID \\
\hline GrA-42891 & Charcoal & B8 & oven fill CC & 7280 & 45 & -22.64 & 58 & $\begin{array}{l}6215-6135(49.0 \%) \\
6115-6080(19.2 \%)\end{array}$ & SN07-569 \\
\hline GrA-42893 & Charcoal & B8 & hearth fill FI & 7355 & 45 & -25.91 & 57 & $6340-6100(68.2 \%)$ & SN08-198 \\
\hline GrA-42894 & Charcoal & B8 & oven fill FZ & 7350 & 45 & -22.04 & 50 & $6330-6095(68.2 \%)$ & SN08-471 \\
\hline GrA-42855 & Charcoal & B7 & pit fill BC & 7245 & 45 & -23.57 & 56 & $\begin{array}{l}6210-6135(35.8 \%) \\
6110-6055(32.4 \%)\end{array}$ & SN07-081 \\
\hline GrA-42856 & Charcoal & B7 & pit fill BE & 7375 & 45 & -23.59 & 61 & $6365-6120(68.2 \%)$ & SN07-083 \\
\hline GrA-42858 & Charcoal & B7 & pit fill GG & 7290 & 45 & -23.35 & 58 & $\%)$ & SN08-467 \\
\hline GrA-42859 & Charcoal & B7 & oven fill GB & 7325 & 45 & -23.13 & 58 & $\begin{array}{l}6235-6200(19.2 \%) \\
6195-6100(49.0 \%)\end{array}$ & SN08-470 \\
\hline GrA-42860 & Charcoal & B7 & oven fill GC & 7215 & 45 & -22.61 & 58 & $6205-6015(68.2 \%)$ & SN08-472 \\
\hline GrA-42869 & Charcoal & B7 & oven fill CB & 7225 & 45 & -24.12 & 61 & $\%)$ & -515 \\
\hline GrA-42846 & Charcoal & B6 & hearth fill $\mathrm{CO}$ & 7360 & 45 & -23.51 & 59 & $6350-6100(68.2 \%)$ & SN07-180 \\
\hline GrA-42848 & Charcoal & B6 & hearth fill CE & 7285 & 45 & -23.24 & 58 & $\begin{array}{l}6215-6130(50.6 \%) \\
6125-6090(17.6 \%)\end{array}$ & SN07-183 \\
\hline GrA-42849 & Charcoal & B6 & oven fill BF & 7250 & 45 & -24.29 & 59 & $\begin{array}{l}6210-6135(38.1 \%) \\
6110-6060(30.1 \%)\end{array}$ & SN07-371 \\
\hline GrA-42853 & Charcoal & B6 & hearth fill & 7240 & 50 & -23.21 & 56 & $\begin{array}{l}6210-6135(33.9 \%) \\
6110-6050(34.3 \%)\end{array}$ & SN08-060 \\
\hline GrA-42854 & Charcoal & B6 & $\begin{array}{l}\text { bin fill sur- } \\
\text { rounded by } \\
\text { ET/EU/EY }\end{array}$ & 7200 & 45 & -21.93 & 52 & $6095-6005(68.2 \%)$ & SN08-158 \\
\hline GrA-42839 & Charcoal & B5 & $11 \mathrm{CC}$ & 7140 & 45 & -23.35 & 59 & $5985(68.2 \%)$ & SN07-347 \\
\hline GrA-42840 & Charcoal & B5 & $11 \mathrm{BW}$ & 7180 & 50 & 24.36 & 63 & 608 & 349 \\
\hline GrA-42843 & Charcoal & B5 & $\mathrm{BN}$ & 7195 & 45 & -23.37 & 56 & o) & 355 \\
\hline GrA-42844 & Charcoal & B5 & oven fill $\mathrm{BH}$ & 7090 & 45 & -23.05 & 58 & $\begin{array}{l}6020-5970(38.3 \%) \\
5955-5915(29.9 \%)\end{array}$ & SN07-370 \\
\hline GrA-42845 & Charcoal & B5 & oven fill CF & 7240 & 45 & 22.36 & 60 & $\begin{array}{l}6210-6140(32.6 \%) \\
6110-6050(35.6 \%)\end{array}$ & 514 \\
\hline 2887 & Cha & B5 & $1 \mathrm{DO}$ & 7235 & 40 & -25.37 & 60 & $6210-6030(68.2 \%)$ & 567 \\
\hline GrA-42833 & Charcoal & B4 & oven fill $\mathrm{L}$ & 7315 & 40 & -23.52 & 58 & $\begin{array}{l}6230-6200(16.6 \%) \\
6195-6100(51.7 \%)\end{array}$ & SN07-070 \\
\hline 42834 & Charcoal & B4 & $1 \mathrm{M}$ & 7135 & 40 & -23.62 & 56 & $6050-5985(68.2 \%)$ & SN07-074 \\
\hline GrA-42835 & Charcoal & B4 & fill $\mathrm{AV}$ & 7160 & 40 & -23.51 & 57 & $6060-6000$ & SN07-129 \\
\hline GrA-42836 & Charcoal & B4 & oven fill AN & 6045 & 40 & -22.69 & 56 & $\begin{array}{l}5005-4895(61.6 \%) \\
4870-4850(6.6 \%)\end{array}$ & SN07-148 \\
\hline GrA-42838 & Charcoal & B4 & $\begin{array}{l}\text { silo/oven fill } \\
\text { AR }\end{array}$ & 7020 & 45 & -23.48 & 56 & $5985-5845(68.2 \%)$ & SN07-160 \\
\hline 822 & oal & B3 & $1 \mathrm{AJ}$ & 7200 & 45 & 3.99 & 57 & & \\
\hline 2824 & Woo & B3 & & 6530 & 40 & 3.96 & 54 & 553 & SN07-163 \\
\hline GrA-42825 & Charcoal & B3 & Fill & 7130 & 45 & -23.69 & 53 & -5985 & SN07-194 \\
\hline GrA-41269 & Charcoal & - & $\begin{array}{l}\text { sample from } \\
\text { Oven T }\end{array}$ & 9730 & 50 & -12.24 & 3 & $9275-9180(68.2 \%)$ & SN08-042 \\
\hline GrA-41271 & $\begin{array}{l}\text { Charcoal } \\
+ \text { roots }\end{array}$ & - & oven fill $U$ & 5140 & 40 & 21.87 & 23 & $\begin{array}{l}3990-3940(45.4 \%) \\
3860-3815(22.8 \%)\end{array}$ & SN08-113 \\
\hline GrA-43008 & $\begin{array}{l}\text { Charcoal } \\
+ \text { roots }\end{array}$ & - & oven fill AK & 7010 & 45 & -24.89 & 27 & $\begin{array}{l}5980-5945(21.1 \%) \\
5925-5845(47.1 \%)\end{array}$ & SN08-365 \\
\hline GrA-32993 & Charcoal & - & $\begin{array}{l}\text { Burial } 03 \\
\text { (LN): grave } \\
\text { fill AG }\end{array}$ & 7200 & 35 & -26.34 & 63 & $6080-6015(68.2 \%)$ & SN05-203 \\
\hline GrA-32996 & Charcoal & - & $\begin{array}{l}\text { Burial } 03 \\
\text { (LN): grave } \\
\text { fill AG }\end{array}$ & 7460 & 80 & -22.70 & 61 & $6405-6245(68.2 \%)$ & SN05-273 \\
\hline
\end{tabular}

